\title{
Article \\ Improvement of sickle cell disease morbi-mortality in children: experi- ence gained in a remote area of an African country
}

\author{
Benoît Mukinayi Mbiya ${ }^{1,2}$, Didier Kalenda Kalombo ${ }^{1,2}$, Yannick Nkesu Mukendi ${ }^{1,2}$, Valery \\ Daubie $^{3}$, John Kalenda Mpoyi ${ }^{2}$, Parola Mukendi Biboyi ${ }^{2}$, Ghislain Tumba Disashi ${ }^{4}$ and Béatrice \\ Gulbis ${ }^{5, *}$.
}

1 Pediatrics Department, Faculty of Medicine, University of Mbujimayi, 06201, Mbujimayi, Democratic Republic of Congo; benoit.mbiya@um.ac.cd (B.M.M.); drkalombodidier@gmail.com (D.K.K.), yannicmukendi@gmail.com (Y.N.M)

2 Sickle Cell Referral Center, Clinique Pédiatrique de Mbujimayi - Pediatrics Clinic of Mbujimayi, 06201, Mbujimayi, Democratic Republic of Congo; johnmpoyi2@gmail.com (J.K.M.); parola.biboyi@cpmrdc.com (P.M.B.)

3 Clinical Biology Department, Laboratoire Hospitalier Universitaire de Bruxelles-University Laboratorium Brussel, Université Libre de Bruxelles, 1070 Brussels, Belgium. Valery.DAUBIE@lhub-ulb.be (V.D.)

${ }^{4}$ Internal Medicine Department, Faculty of Medicine, University of Mbujimayi, 06201, Mbujimayi, Democratic Republic of Congo; recteur@um.ac.cd (G.T.D.)

${ }^{5}$ Clinical Chemistry Department- Hereditary Red Blood Cell Disorders, Laboratoire Hospitalier Universitaire de Bruxelles-University Laboratorium Brussel, Université Libre de Bruxelles, 1070 Brussels, Belgium; Beatrice.GULBIS@lhub-ulb.be (B.G.)

* Correspondence: Beatrice.GULBIS@lhub-ulb.be

Received: date; Accepted: date; Published: date 


\begin{abstract}
Background: Sickle cell disease (SCD) is a public health problem in the Democratic Republic of Congo. If reference sickle cell centers have been implemented in capital-cities of African countries and have proven to be beneficial for SCD patients, it has never been set up ina rural area for families with very low sources of income.
\end{abstract}

Method: A cohort of 143 children with SCD aged 10 years old (IQR [inter quartile range]: 6-15 years) (sex ratio male: female $=1.3$ ) were clinically followed for 12 months without any specific intervention, outside management of acute events , and then 12 months with a monthly medical visit , a biological follow-up and regular prophylaxis.

Results: The median age of patients at the diagnosis of SCD was 2 years (IQR: 1-5). The implementation of standardized and regular follow-up in a new sickle cell referral center in a remote city showed an increase in the annual mean hemoglobin level from 50 to $70 \mathrm{~g} / \mathrm{L}(\mathrm{p}=0.001)$, and a decrease of the lymphocytes count and spleen size $(p<0.001)$. A significant decrease $(p<0.001)$ in the average annual number of hospitalizations and episodes of vaso-occlusive crises, blood transfusions, infections, and acute chest syndromes were also observed.

Conclusions: Creation of a sickle cell referral center and a regular follow-up of children with SCD are possible and applicable in the context of a remote city of an African country. Those simple and accessible measures can reduce the morbimortality of the sickle cell children.

Keywords: sickle cell disease. feasibility. regular follow-up. remote area. Democratic Republic of Congo 


\section{Introduction}

The world's leading genetic disease, sickle cell disease (SCD) has been declared a public health priority by the United Nations (2008, 63rd session of the UN General Assembly). According to the study conducted by Piel et al. in 2017, Africa would have more than 250,000 births of children with a severe form of the disease [1]. In the absence of early and appropriate care, $50 \%$ to $90 \%$ of these newborns will die before the age of 5 [2]. In Central Africa, the incidence of SCD at birth is estimated to be 1 to $2 \%$, the highest in the world. After Nigeria, the Democratic Republic of Congo (DRC) contributes significantly to the high number of SCD patients in sub-Saharan Africa [3].

Of the estimated general population of $91,994,000$, the DRC has $25-30 \%$ carriers of the disease gene (heterozygous AS) and 2 to $3 \%$ of SS homozygotic newborns, with the annual number of newborns with SCD, estimated to be $40,000[4,5]$. Without major changes in the expansion of the endemic disease, the number of people affected is growing at an uncontrolled rate [6,7]. While these figures are significant from an epidemiological point of view, the disease remains little recognized, resulting in high mortality and morbidity [6,8]. Despite significant progress in reducing under-five mortality in the DRC between 2014 and 2018 [9,10], the situation of SCD remains characterized by very rate of morbidity and mortality $[2,11]$. In the absence of routine neonatal screening for SCD, diagnosis is often made in the presence of complications of the disease [5]. Work describing this mortality in cohorts of sickle cell patients followed from birth or with regular medical follow-up is rare in the DRC. Since 1988, it has been demonstrated in high-income countries that neonatal screening can identify affected children and start medical care early before the age of 3 months with the introduction of anti-pneumococcal antibiotic prophylaxis. This strategy significantly improves the mortality and morbidity of the disease [12]. Sectoral studies of neonatal screening and a large clinical trial on the safety and feasibility of hydroxyurea treatment in sickle cell children by Tshilolo et al. in 2009 and 2018 respectively give the proportions of $16.9 \%$ of heterozygous AS and $1.4 \%$ of SS [5], however, neonatal screening is only useful when it is part of an organized care system for affected children [13]. Treatment with hydroxyurea is feasible and safe in children with sickle cell disease living in sub-Saharan Africa. This treatment not only reduces mortality but also reduces various complications like vaso-occlusive events [14]. However, this molecule remains hardly available and too expensie in sub-Saharan Africa [15].

SCD is a major public health concern in the DRC and the basic resources for its management have remained insufficient. Most of the initiatives have been conducted in Kinshasa. If some projects have been set up in Kisangani and Lubumbashi, remote cities such as Mbujimayi, Kanaga etc. have never received support for improving the management of SCD. On the other hand, the DRC has a National SCD Control Program (PNLCD) since December 2001 providing a complete protocol: treatment protocol, national policy, standards, and guidelines, etc. Unfortunately due to lack of necessary resources it can't play efficiently its role. For example, the PNLCD integrated the protocal in 4 of 26 provinces in DRC (Kuilu, Congo-central, Haut-Katanga, and Kinshasa). It explains the little attention paid to the fight against SCD especially in remote areas like the city of Mbujimayi in the center of the country. In the DRC, some existing initiatives are mainly derived or driven by civil society organizations and most often in large cities where specialized centers for the management of SCD can be found. Private impulses are needed to raise awareness and improve the management of this disease for patients living in remote areas. Given the burden of this disease, it is therefore vital to intensify the fight against SCD also in the remote city in sub-Saharan Africa by creating specialized centers for care and setting up regular follow-up of patients at a reduced cost in the absence of completely free care. 
The application of simple, accessible, and less expensive measures accompanied by regular medical monitoring would improve the health of SCD patients in sub-Saharan Africa if applied rigorously [16]. In high-income countries, the survival increase and the better quality of life of SCD patients are less due to sophisticated therapeutics such as stem cell transplantation than to organized systems of early and adequate patient management $[17,18]$. The considerable improvement in the prognosis of SCD achieved by the teams of Serjeant in Jamaica, a country with limited resources, is a remarkable example that shows that, based on suitable strategies, the prognosis of SCD can be improved in Africa [18]. These strategies should include the creation of sickle cell referral centers and integrated care structures within health facilities, the establishment of sickle cell care networks, and the early diagnosis of associated complications by regular medical follow-up. Studies reported on SCD in Africa are mainly retrospective, hospital studies conducted in large cities and capitals. Prospective studies on the optimal follow-up of SCD patients with the rigorous application of management recommendations are rare in Africa [16].

A preliminary investigation conducted in 2015 on the knowledge and behaviors of 50 families affected by SCD in Mbujimayi in the DRC showed that sickle cell children were very ill and there was no referral center specializing in the management of SCD in Mbujimayi. The majority (96\%) families affected by SCD wanted the creation of a referral center for care and $94 \%$ of them had agreed to subscribe to it for the medical follow-up of their affected children. The level of knowledge in families affected by SCD in Mbujimayi is low. Thus, the creation of a referral center and the possibility of a fixed annual amount for the care of patients was a strategy that could be implemented in Mbujimayi to improve the care of sickle cell patients [19].

The objective of the present study was to demonstrate the feasability and affordability of a comprehensive follow-up care for children with sickle cell disease based on the creation of a reference centre in a rural city of DRC for families with very low income.

\section{Patients and Method}

\subsection{Study Context}

This study was conducted in Mbujimayi, which is the capital city of the province of Eastern Kasai in the Democratic Republic of Congo (DRC) (Figure 1). It is the third-largest city in terms of population. Mbujimayi's 2020 population is now estimated to be 2,525,263 (Mbujimayi population data 2020), with an area of $135.12 \mathrm{~km}^{2}$ and a population density of 12,441 inhabitants $/ \mathrm{km}^{2}$. 


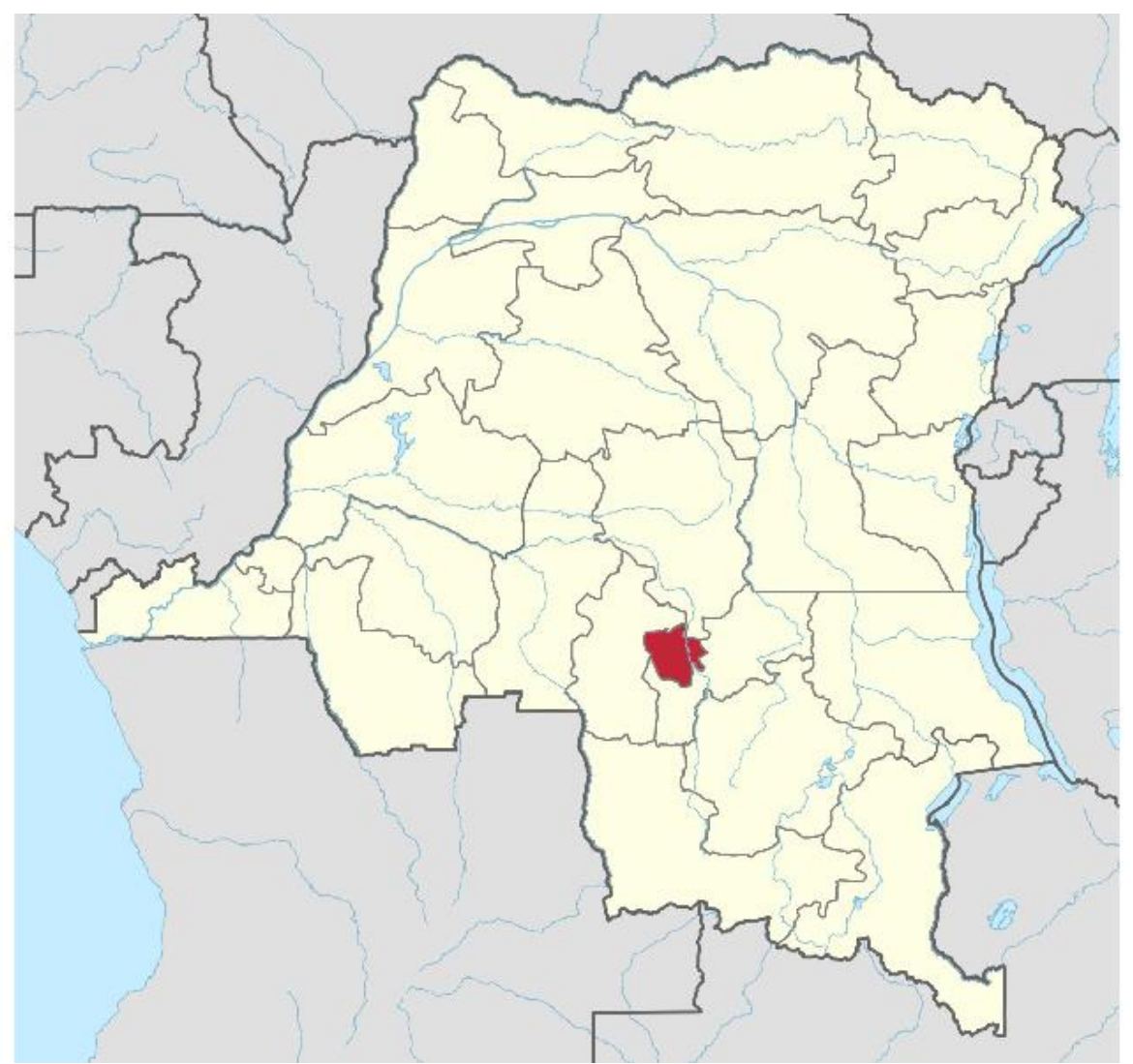

Figure 1. Location of the city of Mbujimayi on the map of the Democratic Republic of Congo (DRC)[20].

In DRC, SCD management is devoted to the National SCD Control Program (PNLCD). In line with the strategy for strengthening the health system, the PNLCD recommendations have not integrated SCD control activities in primary health care structures. The PNLCD is also not implanted in Mbujimayi.

The study was carried out in the Mbujimayi Pediatric Clinic-one of the largest specialized pediatric structures. Currently, it's the structure that organizes the management of SCD with a regular follow-up at no cost to patients in Mbujimayi. It is a reference pediatric structure in the city of Mbujimayi, which is an Eastern Kasai province. It includes a pediatric ward with a capacity of 20 beds that are constantly occupied, a neonatology ward, a maternity ward, and a semi-automated laboratory. However, it is important to note that the city of Mbujimayi has two large old hospitals (Bonzola General Reference Hospital and Dipumba General Reference Hospital). These two hospitals are owned by the Sociéte Minière de Bakwanga (MIBA), the first industrial diamond production company in the DRC. With the fall of MIBA for more than 15 years ago, the company is facing very serious financial difficulties. Its hospitals are abandoned in an advanced state of disrepair and need to be rehabilitated. This has a significant impact on the quality of care to patients, including sickle cell patients. In case of acute complications, sickle cell patients are treated at their own expense and there is generally no follow-up. With the opening of the Mbujimayi pediatric clinic and the organization of free care the influx of sickle cell patients has increased significantly.

\subsection{Study Type and Inclusion Criteria}

From January 2017 to December 2018, we conducted a prospective cohort study including SCD children. These children had never been followed and treated with hydroxyurea before their inclusion in the study. The follow-up of the cohort was 2 years, consisting of a first-year (2017) with a simple follow-up without the application of recommendations for the management of SCD and a second-year (2018) with a classic regular follow-up of the same cohort with the application simple, classic and locally accessible recommendations (Table 2). 
Patients diagnosed with SCD (i.e., sickle cell anemia or sickle cell/Beta-thalassemia) who were older than 3 months and younger than 18 years were eligible for this study. Because neonatal screening was not routinely organized to identify newborns with pre-symptoms, children under 3 months of age were excluded. The diagnosis of SCD was made using an iso-electrofocusing technique (Perkin Elmer, Massachusetts, USA). Blood samples were collected on blotting paper and taken from the laboratory of the Monkole Hospital in Kinshasa, the cape of the DRC. Monkole Hospital is a large centre of sickle cell disease in Kinshasa, DRC. In addition, patients considered for inclusion had to reside in Mbujimayi during the study period. We excluded all SCD children whose primary guardian refused to sign the informed consent and those who were heterozygous AS.

\subsection{Data Collection}

Data were collected during follow-up consultations using a data collection sheet for each patient. Then, these data were transcribed into a common database (Excel file).

\subsection{Study Parameters and Operational Definitions}

Socio-demographic parameters were age, sex, and age at the first diagnosis of SCD (made by a health care provider).

Clinical parameters were the origin of diagnosis (clinical and/or biological), weight (kg), height $(\mathrm{cm})$, weight-for-height Z-score (WHO) assigned by sex and age, symptoms, and palpable size of the spleen. The splenomegaly was classified according to Hackett (WHO, 1963).

Table 1 Study Parameters and Operational Definitions

\begin{tabular}{|c|c|}
\hline Parameters & Operational Definitions \\
\hline Anemia & $\begin{array}{l}\text { The decrease in whole-blood hemoglobin concentration of more than } \\
2 \text { standard deviations below the mean of age- and sex-matched reference } \\
\text { range [21] }\end{array}$ \\
\hline VOC & $\begin{array}{l}\text { Any painful episode requiring in-taking an analgesic (e.g. paracetamol, } \\
\text { ibuprofen, or tramadol) or leading to a medical consultation in a health care } \\
\text { structure. }\end{array}$ \\
\hline Infectious episode & $\begin{array}{l}\text { Any noted increase in the body temperature beyond } 38.5^{\circ} \mathrm{C} \text { that needed to } \\
\text { be managed in a health care facility. }\end{array}$ \\
\hline $\begin{array}{l}\text { Red blood cells } \\
\text { transfusion }\end{array}$ & $\begin{array}{l}\text { Any administration of labile blood products (in particular, packed red blood } \\
\text { cells or whole blood) that occurred in a health care facility. }\end{array}$ \\
\hline $\begin{array}{l}\text { Acute chest } \\
\text { syndrome }\end{array}$ & $\begin{array}{l}\text { Presence of fever, cough, chest pain, difficulty breathing } \pm \text { performing a } \\
\text { chest } x \text {-ray. }\end{array}$ \\
\hline Jaundice & $\begin{array}{l}\text { Was a clinical observation i.e. the presence of a yellow coloration of the } \\
\text { bulbar conjunctiva. }\end{array}$ \\
\hline Hospitalization & Admission to hospital for treatment of at least 24 hours. \\
\hline Adherence to care & $\begin{array}{l}\text { Was assessed as excellent, fair, or poor, depending on the clinical follow-up } \\
\text { observed. }\end{array}$ \\
\hline Large city & $\begin{array}{l}\text { a city with an urban landscape, an international airport that is directly } \\
\text { connected to foreign countries }\end{array}$ \\
\hline Remote city & $\begin{array}{l}\text { urban-rural town in the country and having no direct contact with foreign } \\
\text { countries. }\end{array}$ \\
\hline
\end{tabular}

VOC: vaso-occlusive crisis

Biological parameters were obtained by testing patients with an isoelectric focusing technique and a hemogram (excluding information related to reticulocyte counts). The biological parameters, especially the hemoglobin was used to evaluate the severity of the disease. 
Therapeutic parameters consisted of medications taken. The criteria for prescribing hydroxyurea comprised three or more severe VOC occurring in the last 12 months, SCD-related pain or chronic anemia interfering with daily activities and severe or recurrent episodes of acute chest syndrome $[22,23]$.

\subsection{Medical Monitoring}

Patients were subjected to a 2-year follow-up process comprising a monthly planned medical visit with a clinical and hematological assessment The first year period (2017), medical staff (doctors, nurses) and community relays received training on diagnosis, management of sickle cell disease and for the implementation of standardized follow-up in year 2. This first year was undergone without the application of any recommendations, while the second year (2018) was organized with the systematic application of a standardized and regular follow-up (see Table 2).

Table 2. The follow-up of sickle cell patients and strategy for adhesion.

\begin{tabular}{|c|c|c|}
\hline $\begin{array}{l}\text { Parameters of medical } \\
\text { monitoring }\end{array}$ & Year 1 & Year 2 \\
\hline $\begin{array}{l}\text { Parental Counseling } \\
\text { and Education }[\mathbf{2 2 , 2 4 -} \\
\text { 26] }\end{array}$ & $\begin{array}{l}\text { - Early identification of fever, } \\
\text { VOC, anemia, broad spleen, } \\
\text { and its urgent consultation } \\
\text { for management } \\
\text { - Report any acute events } \\
\text { (VOC, Acute Anemia, Fe- } \\
\text { ver, etc.) }\end{array}$ & $\begin{array}{l}\text { Education on the need for adequate nutrition, hydra- } \\
\text { tion, and regular hospital follow-up. } \\
\text { Early identification of fever and its urgent treatment, } \\
\text { and of a large spleen. } \\
\text { - Use of prophylactic medications like Penicillin V, fo- } \\
\text { lic acid, anti-malarial drugs (sulfadoxine-py- } \\
\text { rimethamine every two weeks), and deworming } \\
\text { with mebendazole (once every six months). }\end{array}$ \\
\hline Immunization [27] & $\begin{array}{l}\text { Checking the vaccine } \\
\text { schedule } \\
\text { No stimulation to get } \\
\text { full vaccination cover- } \\
\text { age }\end{array}$ & $\begin{array}{l}\text { Immunization against infections according to the vac- } \\
\text { cines recommended in the DRC: } \\
\text { - Bacillus Calmette and Guérin vaccines against tuber- } \\
\text { culosis. } \\
\text { - Diphtheria, tetanus, and whooping cough. } \\
\text { - } \quad \text { Oral polio. } \\
\text { - Measles. } \\
\text { - Yellow fever. } \\
\text { - } \quad \text { Tetanus. } \\
\text { - Hemophilus influenza type b; } \\
\text { Pneumococcus (Prevenar 13). }\end{array}$ \\
\hline Strategy for adhesion & $\begin{array}{l}\text { Setting upof a notification } \\
\text { book of acute complica- } \\
\text { tions (fever, pain, acute } \\
\text { anemia, etc.) and contains } \\
\text { the contact number } \\
\text { Organize free-of-charge } \\
\text { emergency treatment for } \\
\text { all SCD patients. }\end{array}$ & 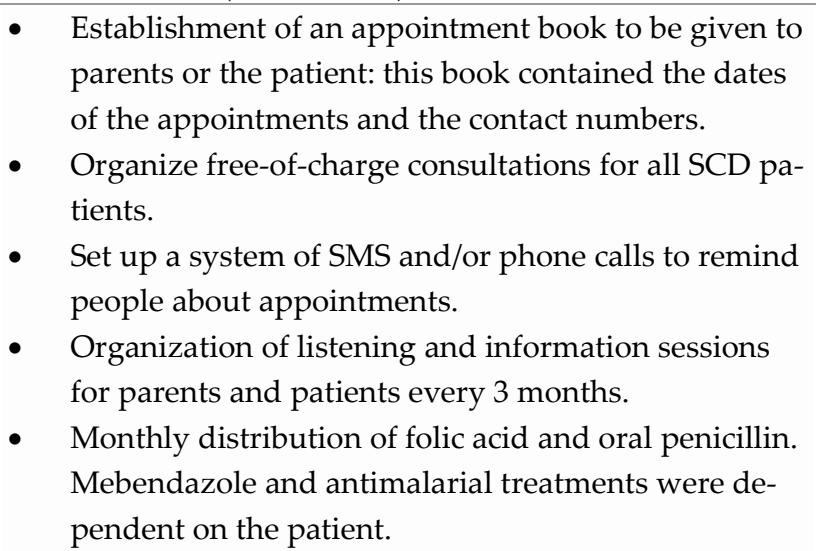 \\
\hline
\end{tabular}

Year 1: follow-up of acute complications and biological parameters without application of conventional recommendations. Emergency support only. 
Year 2: standardized and regular follow-up with the implementation of recommendations for the management of sickle cell disease (Habibi 2015, WHO) adapted to local conditions.

VOC: vaso-occlusive crisis, SCD: sickle cell disease. SMS: short message service. NB: No patients were treated with hydroxyurea because of the drug's low availability and high cost.

* The minimum vaccine coverage proposed/funded in the DRC includes the Calmette and Guerin bacillus vaccine (BCG) against tuberculosis; vaccine against diphtheria, tetanus and whooping cough (DTC); Oral Polio Vaccine (OPV) against polio; measles vaccine (VAR) against measles; the Admiral Vaccine (VAA) against Yellow Fever; and the tetanus vaccine (VAT) against maternal and neonatal tetanus[27].

\subsection{Statistical Analysis}

To analyze blood parameters from children to adulthood patients, data were reported as the percentage of the lower normal limit for corresponding age. Because no criteria are defined for our area in Congo, normal values were compiled from neighboring regions [28-35]. Normal distribution was tested with the D' Agostino \& Pearson normality test. A paired t-test (Gaussian data) or Wilcoxon matched-pairs signed-rank test (no Gaussian data) were used to compare data for each patient. Data were plotted within boxplot $(2.5 \%-97.5 \%$ range). Rate size evolution was analyzed with the Chisquare test and the relation between platelet count and rate size was analyzed by dividing platelets counts by a re-encoded rate size $(\mathrm{h} 0=1, \mathrm{~h} 1=2, \ldots)$.

P-value $<0.05$ was considered as statistically significant $\left(\mathrm{p}<0.05={ }^{*}, \mathrm{p}<0.01={ }^{* *}, \mathrm{p}<0.001={ }^{* * *}\right)$ Statistical analysis were performed with Prism 8.0.1. (GraphPad Software Inc, San Diego, CA) software.

\subsection{Ethical Approval}

All parents or legal respondents of patients provided written informed consent for participation in the study. The study protocol had been reviewed and approved by the Ethics Committee of the Medical Faculty at the University of Mbujimayi (Fac-Méd/UM/CE/012/2016) and the Head Board of the Public Health Division of Eastern Kasai Province (DPSPN71/204/C.E.P.DPS/K.OR/MBM/2016). The study was conducted in agreement with the principles of the Helsinki Declaration II. The aim and procedures of the study were explained to the participants and legal respondents. The participants were informed that they could withdraw anytime, without further obligation. The anonymity of the participants was guaranteed, and no personal details were recorded. The results of this study were presented to parents and legal respondents during a discussion session at the end of the study.

\section{Results}

The process of the study and the recruited cohort of 143 SCD children are described in Figures 2 and 3, respectively. The loss to follow-up and deaths rates during the first year period was $41 \%$ $(104 / 251)$ and $1.6 \%(4 / 251)$, respectively. 


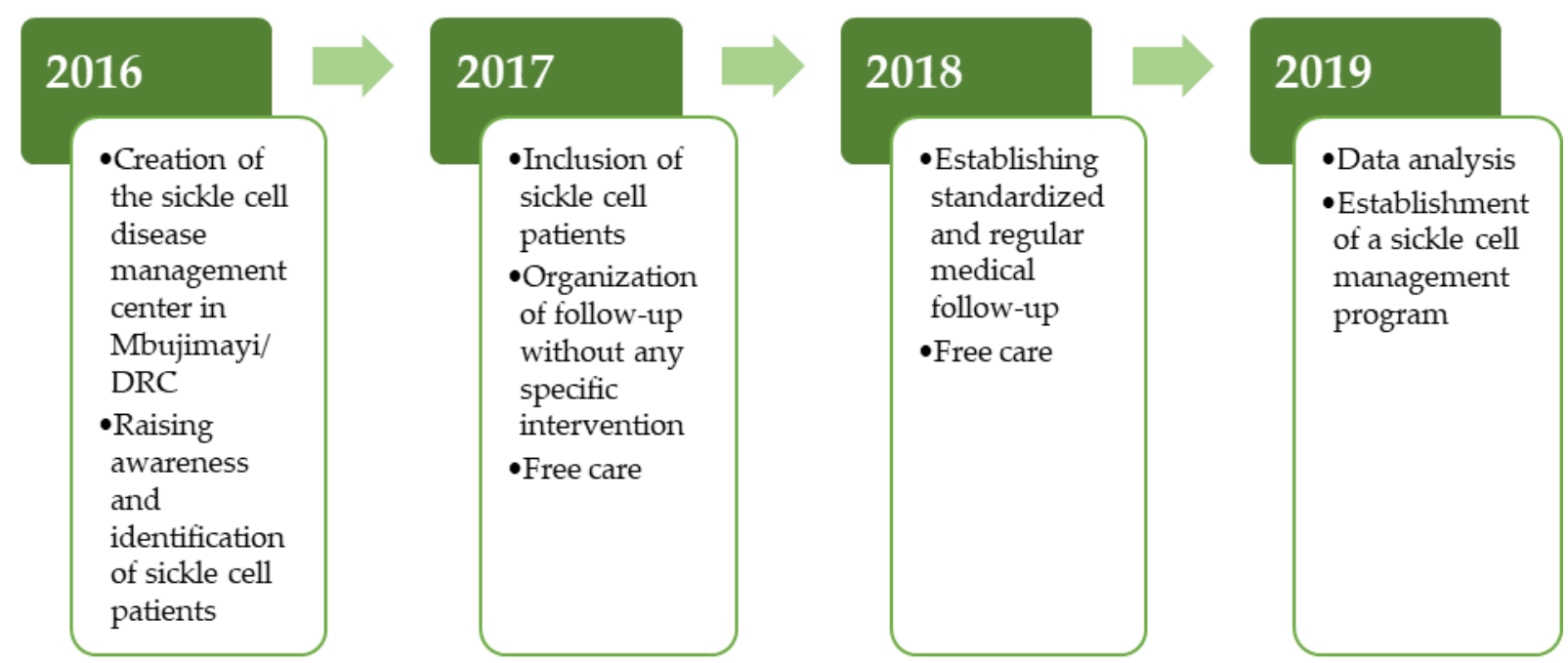

Figure 2. The overall evolution of the study on the application of standardized and regular Follow-up at Mbujimayi in $D R C$.

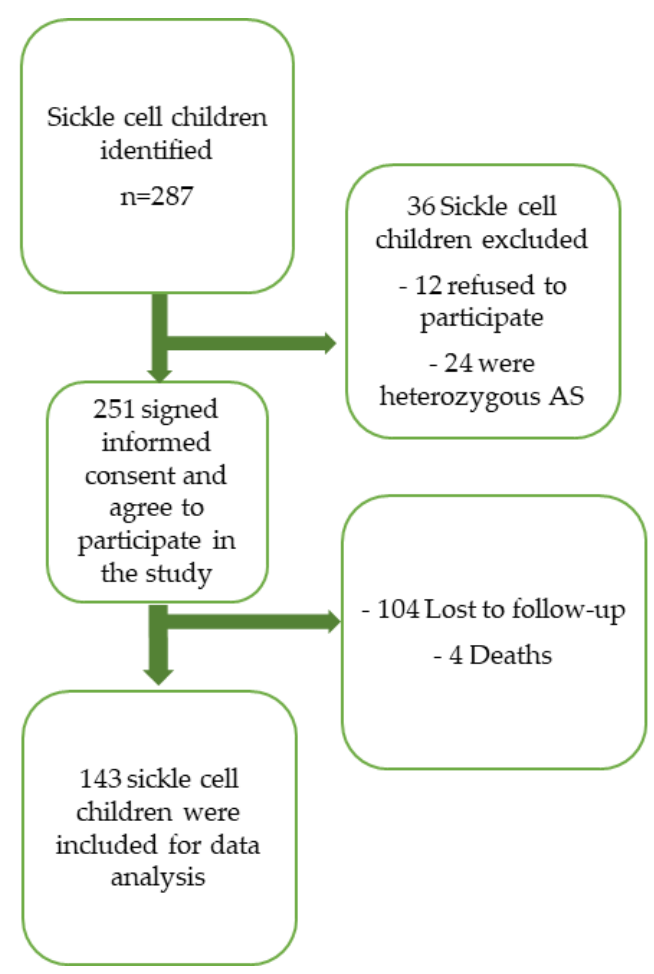

Figure 3. Inclusion of sickle cell children in the study.

The demographic and clinical characteristics of SCD children at 12 months of follow-up (FU) before the implementation of international recommendations are reported in Table 3 . The diagnostic means initially used was predominantly based on clinical features $(43 \%, 62 / 143)$. The circumstances of the diagnosis were mostly VOC (66\%) and anemia (18\%), and none were diagnosed during the neonatal period. The Z-score weight for height $<-2 \mathrm{DS}$ was observed in $47 \%$ of the patients. 
Table 3. Demographic and clinical characteristics of sickle cell children at 12 months of followup, before the implementation of sickle cell management recommendations $(n=143)$

\begin{tabular}{|c|c|c|c|}
\hline Variable & Median (IQR 25\%-75\%) & $\mathrm{n}$ & $\%$ \\
\hline Age & 10 (IQR: 6-15 Years) & & \\
\hline \multirow[t]{5}{*}{ Age at diagnosis } & 2 (IQR: 1-5 Years) & & \\
\hline & Before 1 year & 53 & 37 \\
\hline & Between 1 and 5 years old & 55 & 39 \\
\hline & Between 5 and 10 years old & 22 & 15 \\
\hline & After 10 years & 13 & 9 \\
\hline Sex & Female & 62 & 43 \\
\hline Schooling & Yes & 99 & 69 \\
\hline Z-score weight-for-height $<-2 \mathrm{DS}$ & Yes & 67 & 47 \\
\hline \multirow[t]{3}{*}{ Mode of the first diagnosis } & Clinical & 62 & 43 \\
\hline & Electrophoresis of $\mathrm{Hb}$ & 44 & 31 \\
\hline & Emmel test & 37 & 26 \\
\hline \multicolumn{4}{|l|}{ Circumstances of the first diagnosis } \\
\hline & Vaso-occlusive crisis & 94 & 66 \\
\hline & Anemia & 25 & 18 \\
\hline & $\begin{array}{l}\text { Screening at the time of inclu- } \\
\text { sion }\end{array}$ & 14 & 10 \\
\hline & Fever & 8 & 6 \\
\hline & Jaundice & 2 & 1 \\
\hline & Neonatal screening & 0 & 0 \\
\hline $\begin{array}{l}\text { Confirmation of diagnosis by Iso electro focus- } \\
\text { ing }\end{array}$ & Yes & 143 & 100 \\
\hline Chronic complications & Yes & 31 & 22 \\
\hline \multirow{6}{*}{ Type of complications } & Hip arthritis & 13 & 11 \\
\hline & Stroke & 7 & 5 \\
\hline & Right eye blindness & 1 & 1 \\
\hline & Osteomyelitis & 4 & 3 \\
\hline & Leg ulcer & 3 & 2 \\
\hline & Other & 3 & 2 \\
\hline \multirow{4}{*}{ Reasons for hospitalizations } & Vaso-occlusive crisis & 45 & 31 \\
\hline & Infectious episodes & 34 & 24 \\
\hline & Anemia/blood transfusion & 24 & 17 \\
\hline & Other causes & 40 & 28 \\
\hline Presence of hepatomegaly & Yes & 86 & 60 \\
\hline Presence of jaundice & Yes & 126 & 88 \\
\hline Presence of splenomegaly & Yes & 98 & 69 \\
\hline \multirow[t]{6}{*}{ spleen measurement (according to Hacket) } & $\mathrm{HO}$ & 45 & 31 \\
\hline & $\mathrm{H} 1$ & 16 & 11 \\
\hline & $\mathrm{H} 2$ & 34 & 24 \\
\hline & $\mathrm{H} 3$ & 24 & 17 \\
\hline & $\mathrm{H} 4$ & 15 & 10 \\
\hline & $\mathrm{H} 5$ & 9 & 6 \\
\hline
\end{tabular}

IQR: interquartile range, H0: Hackett stage 0 (no splenomegaly), H1: splenomegaly stage 1 of Hackett, H2: splenomegaly stage 2 of Hackett, H3: splenomegaly stage 3 of Hackett, H4: splenomegaly stage 4 of Hackett, H5: splenomegaly stage 5 of Hackett 


\section{Comparison of Data before and after the Implementation of a Standardized and Regular Follow-Up}

After one year of implementation of standardized and regular follow-up, an overall reduction of the annual average of clinical complications, i.e., VOC, infectious episodes, acute chest syndrome, blood transfusions and hospitalizations (Table a). Due to the variation in reference ranges of the considered biological parameters with age, to evaluate the evolution of those parameters their results were expressed as the percentage of the lower limit of the reference range. A significant increase in hemoglobin level and platelet count have observed as well as a decrease of lymphocyte count. We did not observe statistical differences for the other hematological parameters. Anemia was observed in $100 \%$ of our cohort and it was severe and normocytic for 115 of them $(80 \%)$.

Table 4a Comparison of acute complications of sickle cell disease before and after the Implementation of a Standardized and Regular Follow-Up

\begin{tabular}{|c|c|c|c|}
\hline & Year 1 & Year 2 & \\
\hline Clinical Parameters & $\begin{array}{l}\text { Follow-up without any inter- } \\
\text { vention } n=143\end{array}$ & $\begin{array}{l}\text { standardized and regular fol- } \\
\text { low-up } n=143\end{array}$ & \\
\hline & Annual average [IQR] & Annual average [IQR] & p-value \\
\hline Vaso-Occlusive Crisis & $3,9[1-6]$ & $1,1[0-2]$ & $<0,001(* * *)$ \\
\hline Infectious episode & $4,0[2-6]$ & $1,1[0-1]$ & $<0,001(* * *)$ \\
\hline Hospitalization & $3,8[2-5]$ & $1,2[0-2]$ & $<0,001(* * *)$ \\
\hline Acute Chest Syndrome & $1,0[0-1]$ & $0,0[0-0]$ & $<0,001(* * *)$ \\
\hline Blood Transfusion & $1,9[1-3]$ & $0,0[0-1]$ & $<0,001(* * *)$ \\
\hline
\end{tabular}

IQR: interquartile range (25\%-75\%), Significant $p$ values $(\leq 0,05)$ appear in bold. 
Table $4 \mathrm{~b}$ Comparison of biological parameters for sickle cell patients before and after the Implementation of a Standardized and Regular Follow-Up

\begin{tabular}{|c|c|c|c|}
\hline & Year 1 & Year 2 & \\
\hline \multirow[t]{2}{*}{ Biological Parameters } & $\begin{array}{l}\text { Follow-up without any in- } \\
\text { tervention }\end{array}$ & $\begin{array}{l}\text { Standardized and regular } \\
\text { follow-up }\end{array}$ & p-value \\
\hline & Median (+/- SD) & Median (+/- SD) & \\
\hline $\mathrm{HB}(\mathrm{g} / \mathrm{L})$ & $50(54 \pm 20)$ & $76(76 \pm 14)$ & $<0,001$ \\
\hline $\mathrm{RBC}\left(\times 10^{6} / \mathrm{mm}^{3}\right)$ & $2.0(64 \pm 25)$ & $2.9(86 \pm 19)$ & $<0,001$ \\
\hline HCT (\%) & $15(61 \pm 21)$ & $23(84 \pm 15)$ & $<0,00$ \\
\hline $\mathrm{MCV}(\mathrm{fL})$ & $81(129 \pm 20)$ & $82(125 \pm 13)$ & 0,176 \\
\hline $\mathrm{WBC}\left(\times 10^{3} / \mathrm{mm}^{3}\right)$ & $9.6 \quad(374 \pm 201)$ & $8.4(270 \pm 109)$ & $<0.001$ \\
\hline Lymphocytes (x 103/. $\left.\mathrm{mm}^{3}\right)$ & $4.1(364 \pm 293)$ & $3.2(239 \pm 145)$ & $<0,001$ \\
\hline Neutrophils $\left(\times 10^{3} / \mathrm{mm}^{3}\right)$ & $4.7(375 \pm 205)$ & $4.4(369 \pm 137)$ & 0,554 \\
\hline Platelets $\left(x 10^{3} / \mathrm{mm}^{3}\right)$ & $260(248 \pm 131)$ & $328(317 \pm 108)$ & $<0,001$ \\
\hline
\end{tabular}

HB: hemoglobin, RBC: red blood cells, HCT: hematocrit, MCV: mean corpuscular volume and WBC: white blood cells. The averages of biological parameters represent the percentage of the normal lower limit of the reference range $(\%$ $L L N) \pm S D$ of the evolution of each patient in relation to himself.

The therapeutic characteristics before the implementation of a regular follow-up are described in Table 4. None of the SCD children had been treated with hydroxyurea in the past. Applying the criteria for consensual indications of hydroxyurea treatment ( $\geq 2$ acute chest syndromes per year, Vasoocclusive crisis $\geq 3$ per year, Severe anemia $<70 \mathrm{~g} / \mathrm{L}$ ) in the management of SCD, in the studied cohort $94 \%$ of SCD children need an introduction of hydroxyurea treatment. 
Comparison of the evolution of splenomegaly one year before and one year after the implementation of standardized and regular follow-up showed a statistically significant difference (p-value $<0,001)$ (see Figure 4).

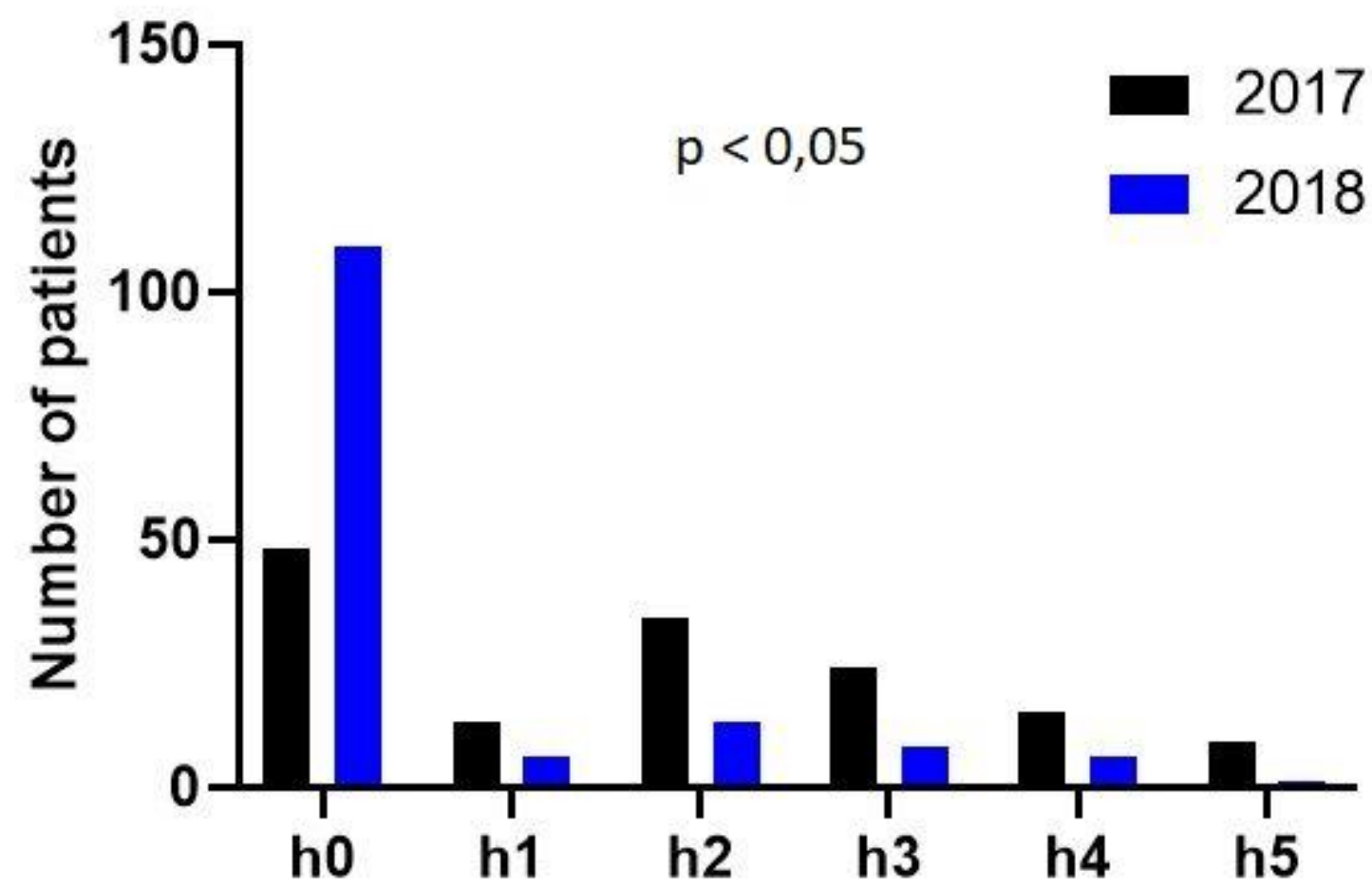

Figure 4: changes in spleen status in sickle cell patients in 2017 (followed without any medical intervention) and 2018 (standardized and regular follow-up). Figure shows statistically significant difference between 2017 and $2018(p<0,0001)$. The clinical classification of splenomegaly according to Hackett (WHO, 1963) includes 5 categories ranging from 0 to 5 :from non-palpable spleen, even in deep inspiration (category $0 ;$ h0) to spleen descending well below the navel, exceeding the line passing between the umbilicus and the pubic symphysis (category 5; h5). 
Table 5. Therapeutic characteristics before regular follow-up applying sickle cell management recommendations $(n=143)$.

\begin{tabular}{lcc}
\hline Variable & $\mathrm{n}$ & $\%$ \\
\hline Prophylaxis & 21 & 15 \\
\hline Folic acid and oral penicillin & 81 & 57 \\
\hline Routine vaccine & 0 & 0 \\
\hline Pneumoccocal vaccination (23 valent) & 0 & 0 \\
\hline Antimalarial & 0 & 0 \\
\hline Dewormers & & 0 \\
\hline Hydroxyurea treatment & 0 & 07 \\
\hline Traditional treatment & 96 & 94 \\
\hline Indication for hydroxyurea treatment & 134 \\
\hline
\end{tabular}

\section{Discussion}

This current study took place at the support center for SCD created in Mbujimayi- a remote city - in Kasai Oriental province in the DRC (around 2.5 million inhabitants) [36]. It aimed to establish a reference center of sickle cell disease that would offer comprehensive outpatient and inpatient care, to the establishment of regular, standardized medical follow-up of patients and to estimate whether is feasible and affordable in a remote city. Additional goals were to observe the results after one year of implementation of a regular medical follow-up, to estimate the need for the introduction of treatment by hydroxyurea and if all the tools would be in place to ensure adequate medical followup for those who would be treated by hydroxyurea. A cohort of 143 SCD children with a median age of 10 years was followed for 2 years. The first year, follow-up was limited to the management of acute complications of the disease (VOC, acute anemia, infection episodes, acute chest syndrome, etc.) without other specific interventions and the second year with the implementation of a standardized and regular follow up. Results at 12 months of regular, standardized medical follow-up and parents' education, without treatment introduction by hydroxyurea, shows an overall reduction of acute complications, i.e. vaso-occlusive crises, infectious episodes, acute chest syndrome, episodes of blood transfusions and hospitalizations, and improvement of anemia. The results showed that the intervention of a newly established sickle cell referral center with evidence-based guidelines has a positive impact on a reduction in morbi-mortality. The regular follow-up of SCD patients including a hematological follow-up are possible and applicable, before the introduction of hydroxyurea treatment, in the context of a remote city in a remote city in DRC.

Creating a support center located close to patients that organize free-of-charge care allowed the current study to be conducted. This is one of the recommended strategies for effectively reducing the burden of SCD morbimortality [8]. In the context of poverty, the goal of equal access to healthcare can only be achieved if health policies guarantee effective care for all patients. As described in Mali, providing centers and units of competence is vital [37]. These structures, whose missions focus primarily on diagnosis and management, should be local community centers. They are stepstones necessary to promote access to timely care for a great number of SCD patients and at an affordable cost. As reported by the Human Development Index, the majority of patients affected by SCD are those with a limited income [38] and in most African countries, only rich patients can have access to 
basic treatments, such as prophylactic oral penicillin, i.e. in DRC, the cost of SCD management is not affordable for approximately $95 \%$ of patients $[37,39]$.

There are very few referral centers for the management of sickle cell disease in Sub-Saharan Africa[16]. The few centers of reference for sickle cell disease if they exist, are in the capitals and large cities of these countries and not in remote areas. In the DRC, the sickle cell referral centers are in Kinshasa (Monkole Hospital and the SS Centre for Mixed Medicine and Anaemia (CMASS)and Lubumbashi (SCD referral center at Nsendwe Hospital).

In Sub-Saharan Africa, models of sickle cell disease management programs have been proposed in the capitals of some countries. Note the Center for Research and control for SCD (CRLD) in Bamako au Mali [40], the National Centre for The Reference of Sickle cell disease (CNRD) in Brazzaville, Republic of Congo [41], National Sickle Cell Disease Center in Cotonou, Benin [42] etc. All of these centres are almost privately funded (including in the DRC). The model implemented was based on neonatal screening for sickle cell disease as part of a project and follow-up of long-term sickle cell patients. The cost of care for patient-dependent follow-up. Although these projects have received government support in their implementation, these programmes remain limited at the capital level and the positive impetus for neonatal screening being stopped with the end of funding and/or remains non-systematic, at the expense of patients and at a high cost to families. This model has not integrated the primary health care system into the intar of malaria, tuberculosis or HIV that are properly managed at health centre levels even in remote areas of Sub-Saharan Africa. A major barrier to progress has been the absence of large-scale early-life screening [43], the high cost of screening with conventional methods (hemoglobin electrophoresis) as well as the lack of standardized and systematic medical follow-up to all patients screened [16]. In the last few years, novel inexpensive SCD point-of-care test kits have become widely available and have been deployed successfully in African field settings. These kits could potentially enable universal early SCD screening. Other recent developments are the expansion of the pneumococcal conjugate vaccine towards near-universal coverage, and the demonstrated safety, efficacy, and increasing availability and affordability of hydroxyurea across African continent. Most elements of standard healthcare for SCD children that are already proven to work in the West, could and should now be implemented at scale in Africa countries [43].

Outside the capitals, care centers are rare and can be found only in some large cities in sub-Saharan African countries. For example In Senegal, an SCD center can be found at the Peace Hospital in Ziguinchor, a town in southern Senegal [44], but the model of the program remains the same as the one described above in the capitals. To date, these centers serve only sickle cell patients living in capitals and large cities and a few patients transferred from remote provinces with financial means. As rural areas in sub-Saharan Africa are destitute, many sickle cell patients in these areas are financially unable to travel to large cities for treatment. The solution that can be envisaged to take care of all patients is to open antennas throughout ces countries [45] and implementing amodel of integration into primary health care. However, a few questions are worth asking: What should be the status of a Sickle Cell Reference Center in Africa? What should be its missions? What should be the policies for access to sickle cell patients to specific care in Africa? How to involve the African States in the design and implementation of these policies? How to organize the management of cases in poor rural areas with limited access to basic health structures?[46]. To answer these questions, Sickle cell disease has been recognized to have global health significance by key institutions including the World Health Organization in 2006 and the United Nation is 2008. In 2010, the WHO released national health care management goals and set targets to be achieved by the countries in Sub-Saharan

Africa for the control and management of SCD. These are yet to be translated into action. To do, this would require active and sustainable public-private partnerships for sustainable program development in these regions. Effective interventions should be integrated into existing health systems, the 
best examples linking primary healthcare facilities to specialized SCD centers in regional and tertiary healthcare institutions[8]. However multiple constraints require an organization based on a network of health professionals working in sickle cell referral centers with specific missions of research, communication, teaching, the establishment of guidelines for diagnosis, treatment, and prevention, and the centers of competence that will focus primarily on the screening, diagnosis, and management of SCD patients favoring equity in access to care [37]. Despite remaining challenges, several high-SCD-burden African countries have the political will and infrastructure for the rapid implementation and scale-up of comprehensive SCD childcare programs. A globally funded effort starting with these countries and expanding elsewhere in Africa and to other high-burden countries, including India, could transform the lives of SCD children worldwide and help countries to attain their Sustainable Development Goals. This endeavor would also require ongoing research focused on the unique needs and challenges of SCD patients, and children in particular, in regions of high prevalence [43].

This study included SCD children for whom the initial diagnosis was never reported being at birth. This initial diagnosis was mainly made based on clinical features only, especially the presence of VOC or anemia. These results are consistent with those of other authors who reported an average age of around 10 years in SCD patients and a first diagnosis at the age of 2 years or later [45,47-51]. VOC being also reported as the most frequent mode of first diagnosis $[44,47,50,52]$.

In this study, patients were subjected to a 2-year follow-up process comprising a monthly planned medical visit with a clinical and hematological assessment. The first year period (2017) was undergone without the application of any intervention, apart from the regulation and treatment of acute complications while the second year (2018) was organized with the systematic application of a standardized and regular follow-up at monthly medical visits, including folic acid and daily oral penicillin prophylaxis, deworming, and antimalarial treatments, as well as a hematological assessment at each visit. In addition, an enhancing adherence process and education to prevent crises were implemented. The results of the first year of follow-up showed that sickle cell children without any specific medical intervention presented severe clinical and hematological pictures with an annual average of 4 VOCs, 4 infectious episodes, 1 acute thoracic syndrome, 4 hospitalizations demonstrating the severity of the disease in a remote area of a developing country. Annual averages of acute events and degradation of biological parameters similar to the results of this study among SCD patients who have not been followed-up in the past were reported in the literature $[47,50,53-$ 55]; however, those studies did not report the impact of a regular follow-up.

The application of standardized and regular follow-up during 12 months showed encouraging results, with a significant reduction in acute events of the disease i.e. a reduction in episodes of VOC, infectious episodes, blood transfusions, acute thoracic syndromes, hospitalizations and, an increase in the hemoglobin level from 50 to $70 \mathrm{~g} / \mathrm{L}$. The steady-state hemoglobin level of $50 \mathrm{~g} / \mathrm{L}$ before regular follow-up is lower than that reported previously in large cities of the DRC or other African countries $(70 \mathrm{~g} / \mathrm{L})[45,47,50,56]$. It could be explained by the lack of optimal management of the disease in the past but also by other factors that should be explored. The study also shows that a decrease in the number of white blood cells due to lymphocytes.

The results of this study provide important baseline data for a new referral center in a remote area of the DRC and how such a center can fill gaps to ensure comprehensive management of sickle cell patients. Similar results have been observed on the implementation of a sickle cell disease management program in a tertiary hospital in a remote area of India. Indeed, a recent study conducted in a remote region of West India by a non-governmental organization reported the implementation of a comprehensive SCD program in a secondary level hospital. They registered 404 SCD patients between December 2015 and June 2017 and compared the uptake of proven interventions and indicators of disease severity from one year prior to registration until the end of the study (June 2018). After the introduction of standardized and regular monitoring, they observed a statistically significant decrease in VOC (277 vs 53.4 ), hospitalizations number (49.8 vs 42.2 ), and 
blood transfusions (27.4 vs 17.8) [57]. As for our results, this demonstrates that the implementation of a comprehensive SCD management program can significantly reduce the severity of the disease, this shows that it is possible to set up sickle cell disease centers in remote areas and to organize optimal management.

Studies carried out in high-income countries have sufficiently demonstrated the benefits of standardized and regular medical follow-up of sickle cell patients, with a reduction in acute and chronic complications of the disease and improvement in the quality of life [58-66]. Prospective cohort studies of SCD patients are rare in Africa due to barriers to medical monitoring [37]. However, a cohort study conducted in Benin in 2015 showed that the frequency of VOC was reduced to about one in every two years and some of the patients were crisis-free for as long as five years after implementing comprehensive health care management [67]. In Jamaica, the establishment of early diagnosis and simple prophylactic measures i.e. oral penicillin and parenting diagnosis of splenic sequestration led to a significant reduction in SCD associated deaths [68].

No children enrolled in the new center and followed in this study have been treated with hydroxyurea in the past, however, $94 \%$ of SCD patients included in this study indicated for HU treatment. Indications of hydroxyurea treatment are common in Africa[15]. In a Nigerian study, 65\% of 206 SCD patients indicated for hydroxyurea treatment [69]. The use of hydroxyurea in the treatment of SCD is very low in low- and middle-income countries $[14,15]$. The efficacy and therapeutic benefits of hydroxyurea have been widely documented. It remains the appropriate basic treatment in the management of SCD for African countries and this study proves that its side effects can be monitored $[8,15,15,58,63,70-72]$. However, In low- and middle-income countries, there are many barriers to hydroxyurea treatment. These barriers include ignorance, the non-prescription of the drug by doctors, the cost of the drug, etc. [73,74]. Awareness and advocacy are needed through the creation of care centers. The creation of referral centers and the organization of optimal management of SCD by doctors trained on major sickle cell syndrome would certainly increase knowledge, prescribing, and awareness around the drug. In the Indian series, the number of SCD patients on hydroxyurea was increased from 4 to $98 \%$ after the implementation of a comprehensive program of management of sickle cell disease in a remote tribal area [57].

The creation of a new sickle cell referral center and its positive results is a new model for providing follow-up care and optimal treatment in remote areas. It is an awareness and an ongoing response to the management of SCD for the families concerned. However, the large number of lost to follow-up observed in this study is worrying. This involves strong local strategies to strengthen adherence to care. The referral center must establish early detection and management of the disease. Neonatal screening provides many benefits like prevention of infection by an early start of antibiotic prophylaxis, folic acid, deworming, proper management of malaria, and immunizations against pneumococcal infections; it is feasible in Africa but needs political support for its implementation [75]. That's why, our prospects are to continue the offer of regular and standardized care, planning future research projects to study SCD screening pregnant women during antenatal consultations, organize a routine neonatal screening of all newborns from at-risk pregnancies (AS and SS women) and children under 5 years of age with a sign of call (transfusion history, anemia, notions of pain or repeated fever, etc.), and introduce hydroxyurea treatment to all eligible patients. The use of rapid sickle cell tests coupled with that of malaria and equipping reference centers with a confirmation technique i.e. iso-electrofocusing technique could also be a strategy to consider for remote areas of low- and middle-income countries. A final perspective is to advocate at the government level for free care for all sickle cell children to guarantee regular follow-up. 
The size as well as the severity of the disease of our cohort could be the result of selection bias. Data must be interpreted considering these two aspects. Even if free of charge, if the clinical expression is mild, families are unlikely to come to a medical center. A longer-term study will undoubtedly make it possible to approach these patients and to know the benefit of a comprehensive care program among this patient population.

\section{Conclusions}

This study showed that the creation of a sickle cell referral center and the regular follow-up of children with SCD and the application of SCD management recommendations are possible and applicable in the context of a remote city in a low-and middle-income country. Simple and accessible measures included in conventional recommendations can reduce the morbimortality of these patients in remote areas if applied rigorously with regular follow-up. Also, neonatal screening of newborns from at-risk pregnant women (SS and AS women), screening for children under 5 years of age with an evocative sign, and the introduction of hydroxyurea treatment are future challenges. All this comprehensive care requires strong public and private partnerships to provide quality of care for SCD patients in poor settings.

Author Contributions: Conceptualization, B.M.M. and B.G.; Methodology, B.M.M., G.T.D. V.D. and B.G.; Validation, B.M.M., G.T.D. and B.G.; Formal Analysis, V.D.; Investigation, D.K.K., J.K.M., Y.N.M. and B.M.M.; Resources, P.M.B.; Data Curation, V.D., P.M.B. and B.M.M.; Writing - Original Draft Preparation, B.M.M.; Writing - Review \& Editing, B.M.M., and B.G.; Visualization, B.M.M.; Supervision, G.T.D and. B.G.; Project Administration, B.G.

Funding: This research received no external funding

Acknowledgments: We thank the parents for their cooperation and agreement for their participation in this study. We would also like to thank all the medical staff and laboratory staff at the Mbujimayi Pediatric Clinic for their active participation in the conduct of this study. We thank the "Fondation Roi Baudouin" in Belgium for its financial contribution, which largely contributed to the creation of the "Clinique Pédiatrique de Mbujimayi", without which this work would not have been possible (Conventions: 2015-I4811840-204333, 2016-I4811840205775, 2016-I1131070-206289)

Conflicts of Interest: The authors declare no conflict of interest

\section{References}

1. Piel FB, Steinberg MH, Rees DC. Sickle Cell Disease. N Engl J Med [Internet]. 2017 Apr 20 [cited 2020 Apr 21];376(16):1561-73. Available from: https://doi.org/10.1056/NEJMra1510865

2. Grosse SD, Odame I, Atrash HK, Amendah DD, Piel FB, Williams TN. Sickle Cell Disease in Africa. Am J Prev Med [Internet]. 2011 Dec [cited 2019 Mar 3];41(6):S398-405. Available from: https://www.ncbi.nlm.nih.gov/pmc/articles/PMC3708126/

3. Piel FB, Hay SI, Gupta S, Weatherall DJ, Williams TN. Global burden of sickle cell anaemia in children under five, 2010-2050: modelling based on demographics, excess mortality, and interventions. PLoS Med. 2013;10(7):e1001484.

4. Agasa B, Bosunga K, Opara A, Tshilumba K, Dupont E, Vertongen F, et al. Prevalence of sickle cell disease in a northeastern region of the Democratic Republic of Congo: what impact on transfusion policy? Transfus Med Oxf Engl. 2010 Feb;20(1):62-5. 
5. Tshilolo L, Aissi LM, Lukusa D, Kinsiama C, Wembonyama S, Gulbis B, et al. Neonatal screening for sickle cell anaemia in the Democratic Republic of the Congo: experience from a pioneer project on 31204 newborns. J Clin Pathol. 2009 Jan;62(1):35-8.

6. De Montalembert M, Tshilolo L. [Is therapeutic progress in the management of sickle cell disease applicable in sub-Saharan Africa?]. Med Trop Rev Corps Sante Colon. 2007 Dec;67(6):612-6.

7. Driscoll MC. Sickle cell disease. Pediatr Rev. 2007 Jul;28(7):259-68.

8. Mburu J, Odame I. Sickle cell disease: Reducing the global disease burden. Int J Lab Hematol [Internet]. 2019 [cited 2020 Jan 8];41(S1):82-8. Available from: https://www.mendeley.com/catalogue/sickle-cell-disease-reducing-global-disease-burden/

9. The DHS Program - Congo Democratic Republic: Standard DHS, 2013-14 [Internet]. [cited 2020 Aug 21]. Available from: https://www.dhsprogram.com/what-we-do/survey/surveydisplay-421.cfm

10. Main results of the MICS-Palu survey 2017-2018 [Internet]. [cited 2020 Aug 21]. Available from: https://www.unicef.org/drcongo/en/reports/summary-mics-palu-2017-2018

11. de Montalembert M, Tshilolo L, Allali S. Sickle cell disease: a comprehensive program of care from birth. Hematology [Internet]. 2019 Dec 6 [cited 2020 Mar 26];2019(1):490-5. Available from: https://ashpublications.org/hematology/article/2019/1/490/422638/Sickle-cell-disease-a-comprehensive-program-of

12. Vichinsky E, Hurst D, Earles A, Kleman K, Lubin B. Newborn screening for sickle cell disease: effect on mortality. Pediatrics. 1988 Jun;81(6):749-55.

13. Allaf B, Couque N, de Montalembert M. [Newborn screening of sickle cell disease and management of care.]. Rev Prat. 2019 Apr;69(4):411-6.

14. McGann PT, Williams TN, Olupot-Olupot P, Tomlinson GA, Lane A, Luís Reis da Fonseca J, et al. Realizing effectiveness across continents with hydroxyurea: Enrollment and baseline characteristics of the multicenter REACH study in Sub-Saharan Africa. Am J Hematol. 2018;93(4):537-45.

15. Tshilolo $L$, Tomlinson $G$, Williams $T$, Santos $B$, Olupot-Olupot $P$, Lane A, et al. Hydroxyurea for Children with Sickle Cell Anemia in Sub-Saharan Africa. N Engl J Med [Internet]. 2019 Jan 1 [cited 2019 Jun 12];380(2):121-31. Available from: insights.ovid.com

16. Diallo DA. [Sickle cell disease in Africa: current situation and strategies for improving the quality and duration of survival]. Bull Acad Natl Med. 2008 Oct;192(7):1361-72; discussion 13721373. 
17. $S D, G B, W W$. A successful education program for parents of infants with newly diagnosed sickle cell disease. J Pediatr Nurs [Internet]. 1992 Feb 1 [cited 2020 Jan 21];7(1):52-7. Available from: https://europepmc.org/article/med/1548563

18. Serjeant GR, Serjeant BE. Management of sickle cell disease; lessons from the Jamaican Cohort Study. Blood Rev. 1993 Sep;7(3):137-45.

19. Bm M, Dk K, S M, B G. [Awareness and attitudes of 50 congolese families affected by sickle cell disease: a local survey]. Pan Afr Med J [Internet]. 2018 Jan 11 [cited 2020 Aug 2];29:2424. Available from: https://europepmc.org/article/med/29875906

20. Mbuji-Mayi. In: Wikipedia [Internet]. 2019 [cited 2019 Dec 9]. Available from: https://en.wikipedia.org/w/index.php?title=Mbuji-Mayi\&oldid=917917895

21. Pomeranz AJ, Sabnis S, Busey S, Kliegman RM. Pediatric Decision-Making Strategies E-Book. Elsevier Health Sciences; 2015. 371 p.

22. Yawn BP, Buchanan GR, Afenyi-Annan AN, Ballas SK, Hassell KL, James AH, et al. Management of sickle cell disease: summary of the 2014 evidence-based report by expert panel members. JAMA. 2014 Sep 10;312(10):1033-48.

23. Sickle Cell Anemia Treatment \& Management: Approach Considerations, Hydroxyurea Therapy, Transfusion. 2020 Jan 31 [cited 2020 Mar 27]; Available from: https://emedicine.medscape.com/article/205926-treatment\#d8

24. Rees DC, Williams TN, Gladwin MT. Sickle-cell disease. Lancet Lond Engl. 2010 Dec 11;376(9757):2018-31.

25. Noronha SA, Sadreameli SC, Strouse JJ. Management of Sickle Cell Disease in Children. South Med J. 2016;109(9):495-502.

26. Habibi A, Arlet J-B, Stankovic K, Gellen-Dautremer J, Ribeil J-A, Bartolucci P, et al. Recommandations françaises de prise en charge de la drépanocytose de l'adulte : actualisation 2015. /data/revues/02488663/v36i5sS1/S0248866315600029/ [Internet]. 2015 May 23 [cited 2019 Apr 4]; Available from: https://www.em-consulte.com/en/article/978572

27. Mwamba GN, Yoloyolo N, Masembe Y, Nsambu MN, Nzuzi C, Tshekoya P, et al. Vaccination coverage and factors influencing routine vaccination status in 12 high risk health zones in the Province of Kinshasa City, Democratic Republic of Congo (DRC), 2015. Pan Afr Med J [Internet]. 2017 Jun 21 [cited 2020 Aug 28];27(Suppl 3). Available from: https://www.ncbi.nlm.nih.gov/pmc/articles/PMC5745950/

28. Buchanan AM, Muro FJ, Gratz J, Crump JA, Musyoka AM, Sichangi MW, et al. Establishment of haematological and immunological reference values for healthy Tanzanian children in Kilimanjaro Region. Trop Med Int Health TM IH. 2010 Sep;15(9):1011-21. 
29. Dosoo DK, Asante KP, Kayan K, Adu-Gyasi D, Osei-Kwakye K, Mahama E, et al. Biochemical and hematologic parameters for children in the middle belt of Ghana. Am J Trop Med Hyg. 2014 Apr;90(4):767-73.

30. Humberg A, Kammer J, Mordmüller B, Kremsner PG, Lell B. Haematological and biochemical reference intervals for infants and children in Gabon. Trop Med Int Health TM IH. 2011 Mar;16(3):343-8.

31. Kumwenda NI, Khonje T, Mipando L, Nkanaunena K, Katundu P, Lubega I, et al. Distribution of haematological and chemical pathology values among infants in Malawi and Uganda. Paediatr Int Child Health. 2012;32(4):213-27.

32. Lugada ES, Mermin J, Kaharuza F, Ulvestad E, Were W, Langeland N, et al. Population-based hematologic and immunologic reference values for a healthy Ugandan population. Clin Diagn Lab Immunol. 2004 Jan;11(1):29-34.

33. Odutola AA, Afolabi MO, Jafali J, Baldeh I, Owolabi OA, Owiafe P, et al. Haematological and biochemical reference values of Gambian infants. Trop Med Int Health TM IH. 2014 Mar;19(3):275-83.

34. Quintó L, Aponte JJ, Sacarlal J, Espasa M, Aide P, Mandomando I, et al. Haematological and biochemical indices in young African children: in search of reference intervals. Trop Med Int Health TM IH. 2006 Nov;11(11):1741-8.

35. Santana-Morales MA, Quispe-Ricalde MA, Afonso-Lehmann RN, Berzosa P, Lorenzo-Morales J, Tiziano G, et al. Haemoglobin levels for population from Gambo, a rural area of Ethiopia, and their association with anaemia and malaria. Malar J. 2013 Dec 1;12:435.

36. Mbuji Mayi Population 2020 (Demographics, Maps, Graphs) [Internet]. [cited 2020 Jan 11]. Available from: http://worldpopulationreview.com/world-cities/mbuji-mayi-population/

37. Diallo DA, Guindo A. Sickle cell disease in sub-Saharan Africa: stakes and strategies for control of the disease. Curr Opin Hematol [Internet]. 2014 May [cited 2018 Oct 22];21(3):210-4. Available from: http://content.wkhealth.com/linkback/openurl?sid=WKPTLP:landingpage\&an=00062752-201405000-00009

38. 2013 Human Development Report | Human Development Reports [Internet]. [cited 2020 Jan 21]. Available from: http://hdr.undp.org/en/2013-report

39. Batina SA, Kambale PK, Sabiti MP, Kayembe CT, Gulbis B. Barriers to health care for sickle cell disease patients in the Democratic Republic of Congo. Afr J Health Issues [Internet]. 2017 Dec [cited 2019 Feb 27];Volume 1 Issue 1:2. Available from: http://www.ajhissues.com/abstract.php?article_id=3475 
40. Diallo DA. [The Research Center and the Fight Against Sickle Cell Anemia of Bamako: an example of a North-South public private partnership]. Bull Acad Natl Med. 2013 Jun;197(6):1221-3.

41. Dokekias AE, Ngolet L, Salomon-Andonie J, Nekhai S, Taylor JG. Establishing a national sickle cell disease program in the Republic of Congo. Blood Adv. 2018 30;2(Suppl 1):17-8.

42. Mc R, A G, G A, E A. Newborn screening for sickle cell disease in the Republic of Benin [Internet]. Vol. 62, Journal of clinical pathology. J Clin Pathol; 2009 [cited 2020 Sep 9]. Available from: https://pubmed.ncbi.nlm.nih.gov/19103860/

43. Oron AP, Chao DL, Ezeanolue EE, Ezenwa LN, Piel FB, Ojogun OT, et al. Caring for Africa's sickle cell children: will we rise to the challenge? BMC Med. 2020 Apr 28;18(1):92.

44. Thiam L, Dramé A, Coly IZ, Diouf FN, Seck N, Boiro D, et al. [Epidemiological, clinical and hematological profiles of homozygous sickle cell disease during the intercritical period among children in Ziguinchor, Senegal]. Pan Afr Med J. 2017;28:208.

45. Gbadoé AD, Atsou K, Agbodjan-Djossou OA, Tsolényanu E, Nyadanu M, Dogba AD, et al. [Ambulatory management of sickle cell disease: evaluation of the first year follow up of patients in the pediatric department of Lomé (Togo)]. Bull Soc Pathol Exot 1990. 2001 May;94(2):1015.

46. Le CRLD au Mali | Atelier Drépano [Internet]. [cited 2020 Aug 24]. Available from: https://reseaudrepano.com/?page_id=130

47. Ayéroué J, Kafando $E$, Kam L, Gué $E$, Vertongen $F$, Ferster $A$, et al. [Hemoglobin sickle cell disease: experience of the Yalgado Ouedraogo University Hospital of Ouagadougou, Burkina Faso]. Arch Pediatr Organe Off Soc Francaise Pediatr. 2009 Apr;16(4):316-21.

48. Fernandes TAA de M, Medeiros TMD de, Alves JJP, Bezerra CM, Fernandes JV, Serafim ÉSS, et al. Socioeconomic and demographic characteristics of sickle cell disease patients from a lowincome region of northeastern Brazil. Rev Bras Hematol E Hemoter [Internet]. 2015 May [cited 2018 Oct 23];37(3):172-7. Available from: https://linkinghub.elsevier.com/retrieve/pii/S1516848415000596

49. Akodu S, Diaku-Akinwumi I, Njokanma O. Age at Diagnosis of Sickle Cell Anaemia in Lagos, Nigeria. Mediterr J Hematol Infect Dis [Internet]. 2013 Jan 2 [cited 2019 Mar 3];5(1). Available from: https://www.ncbi.nlm.nih.gov/pmc/articles/PMC3552728/

50. Aloni MN, Kadima BT, Ekulu PM, Budiongo AN, Ngiyulu RM, Gini-Ehungu JL. Acute crises and complications of sickle cell anemia among patients attending a pediatric tertiary unit in Kinshasa, democratic Republic of Congo. Hematol Rep. 2017;9(2):41-5.

51. Macharia AW, Mochamah G, Uyoga S, Ndila CM, Nyutu G, Makale J, et al. The clinical epidemiology of sickle cell anemia in Africa. Am J Hematol. 2017 Nov 23; 
52. Alexandre-Heymann L, Dubert M, Diallo DA, Diop S, Tolo A, Belinga S, et al. Prevalence and correlates of growth failure in young African patients with sickle cell disease. Br J Haematol. 2019 Jan;184(2):253-62.

53. Mukinayi BM, Kalenda DK, Mbelu S, Gulbis B. Connaissances et comportements de 50 familles congolaises concernées par la drépanocytose: une enquête locale. Pan Afr Med J [Internet]. 2018 [cited 2018 Apr 6];29. Available from: http://www.panafrican-med-journal.com/content/article/29/24/full/

54. Kazadi AL, Ngiyulu RM, Gini-Ehungu JL, Mbuyi-Muamba JM, Aloni MN. The clinical characteristics of Congolese children and adolescents suffering from sickle-cell anemia are marked by the high frequencies of epistaxis compared to Western series. Pediatr Hematol Oncol. 2019 Aug;36(5):267-76.

55. Saidi H, Smart LR, Kamugisha E, Ambrose EE, Soka D, Peck RN, et al. Complications of sickle cell anaemia in children in Northwestern Tanzania. Hematology [Internet]. 2016 [cited 2020 Apr 29];21(4):248-56. Available from: https://www.mendeley.com/catalogue/b24cf166b3ae-3b4d-9561-2557d1685bae/

56. Shongo MYP, Mukuku O, Mutombo AM, Lubala TK, Ilunga PM, Sombodi WU, et al. [Hematological and nutritional profile of homozygous sickle cell SS aged 6 to 59 months in Lubumbashi, Democratic Republic of Congo]. Pan Afr Med J. 2015;21:276.

57. Dave K, Chinnakali P, Thekkur P, Desai S, Vora C, Desai G. Attrition from Care and Clinical Outcomes in a Cohort of Sickle Cell Disease Patients in a Tribal Area of Western India. Trop Med Infect Dis [Internet]. 2019 Oct 1 [cited 2020 May 14];4(4). Available from: https://www.ncbi.nlm.nih.gov/pmc/articles/PMC6958453/

58. Ferster A, Vermylen C, Cornu G, Buyse M, Corazza F, Devalck C, et al. Hydroxyurea for treatment of severe sickle cell anemia: a pediatric clinical trial. Blood. 1996 Sep $15 ; 88(6): 1960-4$.

59. Rincón-López EM, Navarro Gómez ML, Hernández-Sampelayo Matos T, Saavedra-Lozano J, Aguilar de la Red Y, Hernández Rupérez B, et al. Low-risk factors for severe bacterial infection and acute chest syndrome in children with sickle cell disease. Pediatr Blood Cancer. 2019;66(6):e27667.

60. Quinn CT, Rogers ZR, McCavit TL, Buchanan GR. Improved survival of children and adolescents with sickle cell disease. Blood [Internet]. 2010 [cited 2020 Apr 29];115(17):3447-52. Available from: https://www.mendeley.com/catalogue/c2688465-4cd2-3b22-b1516bb1bf5f7063/

61. Gaston MH, Verter JI, Woods G, Pegelow C, Kelleher J, Presbury G, et al. Prophylaxis with Oral Penicillin in Children with Sickle Cell Anemia. N Engl J Med [Internet]. 1986 [cited 2020 Apr 29];314(25):1593-9. Available from: https://www.mendeley.com/catalogue/52236b281f4e-3e4b-8af1-fe63f4857474/ 
62. Steinberg MH, Barton F, Castro O, Pegelow CH, Ballas SK, Kutlar A, et al. Effect of Hydroxyurea on Mortality and Morbidity in Adult Sickle Cell Anemia: Risks and Benefits Up to 9 Years of Treatment. J Am Med Assoc [Internet]. 2003 [cited 2020 Apr 29];289(13):1645-51. Available from: https://www.mendeley.com/catalogue/48107e65-38b5-3136-9453-8caacea $1 \mathrm{a} 7 \mathrm{~d} 4 /$

63. Voskaridou E, Christoulas D, Bilalis A, Plata E, Varvagiannis K, Stamatopoulos G, et al. The effect of prolonged administration of hydroxyurea on morbidity and mortality in adult patients with sickle cell syndromes: results of a 17-year, single-center trial (LaSHS). Blood. 2010 Mar $25 ; 115(12): 2354-63$.

64. Shah N, Bhor M, Xie L, Paulose J, Yuce H. Sickle cell disease complications: Prevalence and resource utilization. PloS One. 2019;14(7):e0214355.

65. Lê PQ, Gulbis B, Dedeken L, Dupont S, Vanderfaeillie A, Heijmans C, et al. Survival among children and adults with sickle cell disease in Belgium: Benefit from hydroxyurea treatment. Pediatr Blood Cancer. 2015 Nov;62(11):1956-61.

66. Thomas R, Dulman R, Lewis A, Notarangelo B, Yang E. Prospective longitudinal follow-up of children with sickle cell disease treated with hydroxyurea since infancy. Pediatr Blood Cancer. 2019;66(9):e27816.

67. Odunvbun ME, Okolo AA. Implementing Comprehensive Health Care Management for Sickle Cell Disease in an African Setting. Niger J Paediatr [Internet]. 2015 Jan 1 [cited 2019 Sep 5];42(4):298-302-302. Available from: https://www.ajol.info/index.php/njp/article/view/122425

68. Lee A, Thomas P, Cupidore L, Serjeant B, Serjeant G. Improved survival in homozygous sickle cell disease: lessons from a cohort study. BMJ. 1995 Dec 16;311(7020):1600-2.

69. Aliyu ZY, Babadoko A, Mamman A. Hydroxyurea Utilization in Nigeria, a Lesson in Public Health. Blood [Internet]. 2007 Nov 16 [cited 2020 Mar 27];110(11):80-80. Available from: https://ashpublications.org/blood/article/110/11/80/118231/Hydroxyurea-Utilization-in-Nigeria-a-Lesson-in

70. Luzzatto L, Makani J. Hydroxyurea - An Essential Medicine for Sickle Cell Disease in Africa. N Engl J Med [Internet]. 2019 Jan 1 [cited 2019 Jun 12];380(2):187-9. Available from: insights.ovid.com

71. Zimmerman SA, Schultz WH, Davis JS, Pickens CV, Mortier NA, Howard TA, et al. Sustained long-term hematologic efficacy of hydroxyurea at maximum tolerated dose in children with sickle cell disease. Blood [Internet]. 2004 Mar 15 [cited 2018 Oct 23];103(6):2039-45. Available from: http://www.bloodjournal.org/content/103/6/2039

72. de Montalembert M. [Hydroxyurea treatment in patients affected with sickle cell anemia: efficacy and safety]. Transfus Clin Biol J Soc Francaise Transfus Sang. 2008 Mar;15(1-2):34-8. 
73. Adeyemo TA, Diaku-Akinwunmi IN, Ojewunmi OO, Bolarinwa AB, Adekile AD. Barriers to the use of hydroxyurea in the management of sickle cell disease in Nigeria. Hemoglobin. 2019 May;43(3):188-92.

74. Strouse JJ, Heeney MM. Hydroxyurea for the treatment of sickle cell disease: Efficacy, barriers, toxicity, and management in children. Pediatr Blood Cancer [Internet]. 2012 Aug [cited 2019 Apr 4];59(2):365-71. Available from: http://doi.wiley.com/10.1002/pbc.24178

75. Mulumba LL, Wilson L. Sickle cell disease among children in Africa: An integrative literature review and global recommendations. Int J Afr Nurs Sci [Internet]. 2015 [cited 2018 Oct 24];3:56-64. Available from: https://linkinghub.elsevier.com/retrieve/pii/S2214139115000207 